\title{
Determinants of Small Firm Debt Ratios: An Analysis of Retail Panel Data
}

\begin{abstract}
In this paper, the relevance of some debt ratio determinants from the recent theory of finance is empirically investigated in a small business sector. The data used in this study consist of average financial data of 27 shoptypes in 20 different years, covering a period of 24 years. The panel character of the data facilitates the use of analytical techniques aimed at reducing or avoiding the biasing effect of omitted variables on the outcomes. The main conclusion is, that the theoretical determinants appear indeed to be relevant for the small business sector investigated here, but the influences encountered in the analyses are far less straightforward than the hypothesized effects in the theory. Influences on total debt are frequently found to be the net effects of opposite influences on long and short term debt and some variables show large time and industry specific effects. Further, distinct patterns in the time specific effects were found.
\end{abstract}

\section{Introduction}

The capital structure of the firm has been a contentious issue in the theory of business finance since the publication of Modigliani and Miller's $(1958,1963)$ seminal papers. Their initial conclusions of capital structure irrelevance and, subsequently, of optimal capital structure at a $100 \%$ debt financing are clearly incompatible with observed capital structures, so their findings initiated a considerable research effort to identify costs of debt financing that would offset the corporate tax advantage. Since then, extensions of the Modigliani-Miller theory have been provided

Final version accepted on November 19, 1991

Research Institure for Small and Medium-Sized Business in the Netherlands

Department of Fundamental Research

P.O. Box 7001

NL-2701 AA Zoetermeer

The Netherlands by, among others, Robichek and Myers (1965), Jensen and Meckling (1976), Ross (1977), Leland and Pyle (1977) and Myers (1977). The general result of these extensions is that the combination of leverage related costs (such as bankruptcy and agency costs) and a tax advantage of debt produces an optimal capital structure at less than a $100 \%$ debt financing, as the tax advantage is traded off against the likelihood of incurring the costs.

This theoretical result is now widely accepted in the profession. The main criticism is of empirical nature, i.e. whether or not the various leverage related costs and benefits are economically significant enough to have an appreciable impact on optimal leverage. This criticism gave rise to a number of empirical studies in which either the magnitude of leverage related costs and benefits is directly estimated (e.g. Warner, 1977) or in which observed capital structures are related to operating characteristics which are assumed to reflect these costs and benefits (e.g. Scott, 1972, Remmers et al. 1974, Scott and Martin, 1975, Ferri and Jones, 1979, Flath and Knoeber, 1980, Castanias, 1983, Bradley et al. 1984). Most of these studies use data of firms that would be classified as large by any definition of small business.

The empirical implications of the theory of finance for small business are seldom discussed (McConnell and Pettit, 1984, and Van der Wijst, 1989, are exceptions) and even less frequently empirically tested in a quantitative manner (Keasey and McGuinness, 1990, is a noteworthy example). This means that there is a large discrepancy between the importance of small business in most western economies and the attention devoted to it by the finance profession. Financial research in the field of small business is usually confined to descriptive analyses using either case studies (e.g.

Small Business Economics 5: 55-65, 1993.

(C) 1993 Kluwer Academic Publishers. Printed in the Netherlands. 
Rapoport, 1990) or a behavioural approach (Norton, 1990) or qualitative analyses (Walker, 1989).

In this paper, the relevance of some debt ratio determinants from the recent theory of finance is empirically investigated in a small business sector. These determinants usually refer to factors that can not or not adequately be measured by outside researchers. Consequently, proxy variables have to be used in any empirical investigation and this study is no exception. Although the theoretical assumptions of completeness and perfectness may be less valid for the small firm's capital market than they are for the large firm's, no attempts are made to capture the effects, if any, of the alleged imperfections of the small firm's capital market in testing our hypotheses. Also, the determinants are tested as such, i.e. we are not considering the joint determinants of the investment and the financing decision. Hence, this paper is aimed at a rather straightforward test of the relevance of theoretical determinants. Such tests are scarce in small business, perhaps because empirical analyses of financial structure in small business are frequently hampered by a lack of available data. For the majority of small firms, publication of the annual report is not mandatory and, hence, simply not done. This means that laborious fieldwork or questionnaires have to be used to collect small firm financial statements and this, in turn, means that data collection is usually restricted to some key figures on financial structure without much room for explanatory variables. As a consequence, in empirical analyses important determinants of financial structure often have to be approximated in a rather arbitrary manner or, even worse, simply have to be omitted. This may, of course, bias the results of the analyses. The analytical technique used here reduces or avoids the omitted variables bias. The panel character of the data, which consist of the average financial statements of 27 industries in retailing (shoptypes) in 20 years, permits the use of this technique.

The paper is organized as follows. In section 2, the theoretical determinants of financial structure are briefly summarized. The data used in this study are described in section 3 and section 4 contains the empirical analysis, i.e. the empirical proxy variables, the model specifications and the estimation results. Section 5 concludes the paper.

\section{Debt ratio determinants}

From the combined theoretical and empirical studies of business finance, that have been published over the past three decades, some broad categories of debt ratio determinants can be seen to emerge. These determinants make no explicit distinction between small and large business ${ }^{1}$ and they refer, of course, to the costs and benefits associated with financial contracting. In the $a b-$ sence of costs and benefits, i.e. in the perfect capital markets for which financial economists have such a pronounced bias, the market value of the firm is independent of its capital structure, as the famous Modigliani-Miller irrelevance theorem demonstrates. The market imperfections that have been brought forward as determinants of the firm's optimal capital structure can be collocated in the categories taxes, bankruptcy costs, agency costs and signalling effect. ${ }^{2}$

The influence of taxes on financial structure rests on differences in fiscal treatment between debt and equity: since interest payments are tax deductible and dividends are not, the fiscal regime is generally considered to favour debt. This simple tax effect can be complicated by several factors. First of all, non-debt tax shields, such as depreciation charges and investment tax credits, can reduce the expected tax benefit from interest payments. Secondly, personal taxes can offset the favourable treatment of debt at the corporate level, as Miller (1977) pointed out. Thirdly, aspects of the tax regime can create differences in investors' preferences. For instance, in many countries the tax rates applying to capital gains are lower than those applying to dividend and interest income. This creates a preference for capital gains over dividends from stock ownership, but other aspects can cancel out this effect. Some investors are not taxed, e.g. pension funds or very small investors, who benefit from the fact that small amounts of dividend are usually exempt from taxation. Other investors, such as retired people, may depend on dividend income for their livelihood. ${ }^{3}$ Given the wide variety among investors' tax situations, the combined effect of all these aspects of the fiscal environment can become quite complex. Therefore, it is usually assumed that the net effect of all fiscal rules creates, over a certain range, a positive ta incentive for corporate debt 
financing, albeit that this effect is smaller than in the original Modigliani-Miller theory and that it may not apply equally to all investors.

Without some costs to offset the tax advantage, this incentive will lead to a maximal use of debt financing, which is not observed in practice. The first counterbalancing costs to be suggested by, among others, Robichek and Myers (1965) and Baxter (1967), were the dead-weight losses associated with bankruptcy and reorganization. Bankruptcy costs refer to the added costs (such as legal fees, reduced sales, increased production costs, etc.) that arise because the firm cannot meet its obligations to creditors without changing its operating or external financing activities (Haley and Schall, 1979). The theoretical influence of bankruptcy costs is not contentious but from an empirical point of view the importance is somewhat controversial. The evidence collected in different studies varies from direct bankruptcy costs averaging a trivial $1 \%$ of the market value of the firm prior to bankruptcy to an approximate $20 \%$ of the estate. Most studies agree that some direct costs decline with firm size, stressing the importance for smaller firms. Substantial indirect costs can arise from the imperfection of secondary markets for physical assets. To illustrate, Kim mentions that in a distress sale, assets may bring as little as $30 \%$ of their wholesale price (Kim, 1978, p. 47). All these effects contribute to a reduction in firm value if the possibility of "financial distress" exists, even if bankruptcy in the legal sense is virtually impossible. Hence, increasing the expected value of these costs by choosing high debt levels which increase the probability of bankruptcy will, at a certain point, cancel out the tax advantage.

Perhaps the most powerful concept of leverage related costs was introduced by Jensen and Meckling (1976), who describe the firm as a nexus of relationships that can be characterized as principal-agent relationships. The firm's security holders (debtholders as well as stockholders) can be seen as principals and the firm's management as the agent, managing the principals' assets. This principal-agent relation is costly, because there is a possibility that the agent will not always conduct business in a way that is consistent with the best interest of the principals. Hence, the latter may insist on various types of protective covenants and monitoring devices in order to protect themselves. Monitoring is generally facilitated by using covenants that restrict the entrepreneur's activity, ${ }^{4}$ thereby increasing financing costs. The costs of writing and enforcing these covenants and of employing other monitoring devices may well be substantial. These costs are likely to be comparatively high for small and young firms, because of the lack of formal financial control and the firms' flexibility to change its assets. This makes it difficult to gain insight into their financial performance. Monitoring and bonding costs are likely to increase with the degree of protection they offer. Therefore, security holders will not seek perfect protection, but these agency costs, as Jensen and Meckling call them, will be traded off against the likelihood of a loss resulting from management actions. If agency costs also increase with the proportion of financing supplied by any type of security holder, conformably to Jensen and Meckling's suggestion, it is possible to argue that a capital structure exists in which total agency costs are minimal. In this way, an optimal capital structure may exist even in the absence of taxes and bankruptcy costs.

Additionally, it can be noted that some, if not all, of the firm's financial relationships have information value, as is suggested by Ross' (1977) signalling hypothesis. The financial obligations a firm enters into may serve as signals to the public about the future performance of the firm. Dividend policy is another obvious candidate for a signalling device. Still other signals may spring from the owner/manager's personal financial involvement in the firm, as is suggested by, among others, Leland and Pyle (1977). Signalling activities arise in situations in which information is unevenly distributed over investors and management (i.e. when "information asymmetry" exists) and when moral hazard hampers the direct transfer of information between market participants. Generally, the firm's management are most knowledgeable of its prospects, but they cannot be expected to be entirely straightforward about these prospects for two reasons. First, there may be substantial rewards for exaggerating the firm's positive qualities and obscuring the negative ones, when ascertaining the true qualities by outside parties is costly or impossible. Second, managers can be reluctant to disclose the full merit of the 
firm since this might allow competitors to appropriate key features of the firm's projects. Information asymmetry is particularly pronounced for, again small and young firms in a dynamic industry. These firms usually must incur high costs to generate information for use by outside investors, because much of their expertise and knowledge is intangible and hard to quantify. So, like bankruptcy and monitoring costs, information costs are also likely to be a more important financial structure determinant for small businesses than for large ones.

\section{Data}

The data used in this study refer to the retail trade in the former Western Germany and are publicly available: the information has been published by the collectors for purposes such as interfirm comparisons. The data are based on information of individual firms, but the unit of observation used here is the published "industry average", i.e. the averaged data for narrowly defined shoptypes such as supermarkets and shoe shops. The data have a panel character: information on shoptypes is available for a number of years. ${ }^{5}$

The data were collected by the "Institut für Handelsforschung an der Universität zu Köln" in two separate series of surveys. The first series consists of regular inquiries into the financial situation of the retail trade, made every alternate year over the period 1955 through 1969 and the years 1973 and 1977. The balance sheet data for this study have been taken from two ten year summaries and a periodical, both brought out by the research institute mentioned above. ${ }^{6}$ Because beginning and ending balance sheets were collected, an uninterrupted row of ending balance sheets over the period 1954 through 1969 can be constructed, as well as ending balance sheets for the years 1972, 1973, 1976 and 1977.

The second series of surveys consists of yearly inquiries into the sales, costs, margins and profits of the retail trade over the period 1949 through 1986. In these surveys, information on income statements is collected and published for largely the same shoptypes as in the balance sheet survey. The income statement data for this study have been taken from three ten year summaries brought out by the Cologne institute mentioned earlier.?
Both series of surveys are claimed to be representative of the German retail trade for all variables except size variables (sales size, total assets). From the publications, sales size (and sample size) can be seen to differ between both surveys, but the only ratio they have in common, the inventory turnover, correlates almost perfectly between the surveys (simple correlation coefficient always $>0.94$, usually $>0.97$ ). Hence, it seems safe to use ratios from the income statement survey in the analysis of balance sheet data. The combined surveys contain concise balance sheets, income statements and information on labour volume, shop surface, prices, etc. This information is available for 27 shoptypes over the entire period and for 15 other shoptypes over a part of the period. Only the former 27 shoptypes are used in this study. A more detailed description of the data can be found in the publications referred to earlier. A list of the 27 shoptypes involved and some key financial data per shoptype are appended to this paper. In Figure 1 the development of some leverage ratios over time (averaged across shoptypes) is depicted. Figure 1 shows, that the average financial structure in retailing over the period is largely stable. The share of equity in total assets rises slowly in the fifties, is more or less stable in the sixties and slowly diminishes in the seventies. Total debt shows, of course, the opposite picture but the ratio of long term debt to total assets slowly increases over almost the entire period. Taken as a whole, however, the changes occurring in the period of almost a quarter of a century are remarkably small.

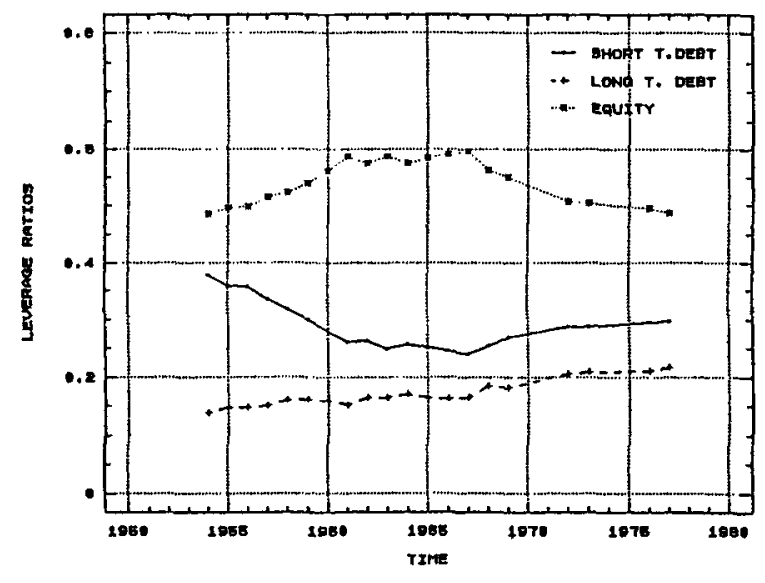

Fig. 1. Leverage ratios over time 


\section{Empirical analyses}

\subsection{Variables}

From the data described in the previous section, the following variables are adopted for the empiri$\mathrm{cal}$ analyses. The obvious choice of variable to be explained is the debt ratio, since all theoretical determinants are formulated in terms of more or less leverage. Estimating separate relations for long and short term debt ratios (long and short term debt to total assets) allows for influences on the maturity structure of debt as well as on leverage. Total assets is included as size variable in the explanation of the debt ratios in order to test for scale effects in the relation between debt and total assets.

The tax effect on debt has to be incorporated in an indirect manner, because no direct measures are available. Following Bradley et al. (1984), depreciation charges are used to indicate non-debt tax shields. ${ }^{8}$ The ratio of depreciation charges to total costs is included in the analyses to indicate the tax advantage. Since depreciation charges can reduce the expected tax benefits from interest payments, this variable is expected to be negatively related to leverage.

Two variables pertaining to the firm's assets are included to capture the effects of bankruptcy and agency costs. Agency costs are, to a large extent, made to avoid bankruptcy costs, so a reduction in the latter also diminishes the need to incur the former. Hence, both determinants are usually approximated with the same variables. Bankruptcy costs can be thought of as the difference between the firm's operating value and its liquidation value, so a high liquidation value makes debt financing more attractive. Since fixed assets are generally considered to offer more security (i.e. a higher liquidation value) than current assets, asset structure (i.e. the ratio of fixed to total assets) is used to indicate the liquidation value. ${ }^{9}$ The second variable to be included, inventory turnover, is not frequently encountered in the literature, but in retailing inventories are a financially (and commercially) important part of the assets. The characteristics of the inventories determine whether or not they are accepted by banks as collateral for loans $\mathrm{s}^{10}$ and this can have a substantial influence on financial structure. Inventory turnover is likely to reflect the liquidity of, and thus, the security offered by the inventories. Both variables are expected to have a positive effect on leverage, but they can also influence the maturity structure of debt, i.e. a large fixed asset component can be associated with a comparatively heavy use of long term debt and a high inventory turnover with relatively much short term debt.

The fifth variable to be included is return on investment, which reflects the possibilities to retain earnings. The importance of these internally generated funds is stressed by Myers (1984) and Myers and Majluf (1984), following the observation that firms seem to prefer raising capital by retaining earnings in the first place, by borrowing in the second place and by issuing new equity in the last place. An explanation of this "pecking order" in financing alternatives, as Myers calls it, can be based on the asymmetrical distribution of information between potential outside investors and the firm's management. When the investors are less knowledgeable of the firm's prospects than its management, a situation may arise in which firms face the dilemma of either passing by projects with a positive net present value or issuing stock at a price they think is too low. This situation can be avoided if a firm can retain enough internally generated funds to cover its positive NPV opportunities or if it can maintain financial slack in the form of "reserve borrowing power". In this view, observed debt ratios will reflect the cumulative requirement for external financing over an extended period, and will be negatively related to profitability. ${ }^{11}$

\subsection{Analyses}

The hypotheses formulated above as a priori expectations are tested by including the five variables in a Least-Squares Dummy Variable (LSDV) regression analysis of the pooled cross section and time series data. Autocorrelation and heteroskedasticity are accounted for in the estimation procedure. Beforehand, the variables expressed as money amounts have been deflated with the industry specific price indices included in the data, ${ }^{12}$ and separate regression equations are estimated for long and short term debt. Since the analysis concentrates on debt ratios as such (and not their changes over time), neither leads and lags 
nor the simultaneities, if any, in the financing and investment decisions are considered. A few remarks may serve to illustrate this research design.

The LSDV technique is chosen because the five variables could very well exhibit important industry and/or time commonalities and, more seriously, they can be correlated with industry and time specific omitted variables. In the latter case, the results of an OLS analysis would partly reflect the influence of the omitted variables rather than the pure effects of the included variables. By introducing shoptype and/or time specific variables into the regression equation, it is possible to reduce or avoid the omitted variable bias (see Hsiao, 1986). The panel character of the data permits these variables to be included. Time and industry specific variables can be included in basically two ways. First, since all variables consist of observations per shoptype repeated over time, they can be averaged across shoptypes per period and across periods per shoptype. If these averages would be added to the regression equation, they would provide insight into the cross-sectional (within group) and time series (between group) characteristics of the variables themselves. This procedure would only capture effects of omitted variables in so far as they are related to the fluctuations in the shoptype and period averages of the included variables.

The second way to include time and industry specific effects is based on the more likely assumption that the effects of shoptype specific omitted variables stay constant through time for a given shoptype but vary across shoptypes. Similarly, the effects time specific omitted variables are likely to be the same for all shoptypes, but will vary in time without necessarily showing any pattern. A simple way to take account of these effects is to use variable-intercept models. Given the above assumptions regarding the effects of omitted variables, they can be absorbed into the intercept term of a regression model as a means to explicitly allow for the individual and time heterogeneity contained in the pooled cross section and time series data (see Hsiao, 1986 or Dielman, 1989). Within the variable-intercept models, the shoptype and period specific effects can be treated as fixed constants (in fixed-effects models) or as random variables (in random-effects models). The 27 shoptypes involved in this study cover a large part of total retailing, so they cannot be considered a small sample from a much larger population of shoptypes. In this situation, the fixed-effects model seems more appropriate than its random-effects counterpart. ${ }^{13}$ Hence, time and industry effects are introduced in this study by estimating the coefficients of a fixed-effects model using the leastsquares dummy variable (LSDV) approach. For all shoptypes and all but the first period a separate dummy variable is included in the regression equation, replacing the intercept. Note that these dummy variables will not only capture the time and industry specific effects of omitted variables, but also the time and industry commonalities in the included variables. ${ }^{14}$

Autocorrelation and heteroskedasticity, which are likely to occur in panel data, are accounted for by using an estimated generalized least squares estimator for the coefficients of the LSDV analysis. ${ }^{15}$ This estimator is obtained by re-running the LSDV regression after a transformation of the data. The transformation is done separately for long and short term debt. The elements of the transformation are obtained as follows. First order autocorrelation coefficients $(\rho)$ are estimated ${ }^{16}$ for the residuals $\left(u_{i l}\right)$ of the original LSDV regressions ( $i$ and $t$ are subscripts for shoptype and time resp.). Residuals corrected for autocorrelation $\left(u_{i t}^{*}\right)$ are calculated as $u_{i t}^{*}=u_{i t}-\rho u_{i t-1} \cdot{ }^{17}$ The squares of the corrected residuals are regressed on the shoptype dummies: $\left(u_{i f}^{*}\right)^{2}=\sigma_{i}^{2} \operatorname{Dum}_{i}+\varepsilon$. The coefficient of this regression, $\sigma^{2}$ provides an estimate of the shoptype specific variance. Using these results, the data $(Z)$ are transformed by: $Z_{i t}^{*}=\left(Z_{i t}-\rho Z_{i t-1}\right) \div \sigma_{i \cdot}{ }^{18}$ The thus transformed data are then used to re-estimate the coefficients of the LSDV model.

The results of the LSDV analyses are reported on in three different ways. First of all, the estimated GLS results regarding the non-dummy variables are presented in Table $I$.

From the coefficients for total assets in Table I it can be seen, that no scale effects in the long and short term debt ratio are found: both coefficients are not significantly different from zero. The hypothesis regarding the tax effect is not supported: the coefficients of depreciation charges are not significantly different from zero and the coefficient for short term debt is even positive, contrary to the expected influence of non-debt tax shields. 
TABLE I

Estimated LSDV regression coefficients (pooled data, corrected ror autocorrelation and heteroskedasticity, standard errors between parentheses)

\begin{tabular}{|c|c|c|c|c|c|c|}
\hline & $\begin{array}{l}\text { Total } \\
\text { assets }\end{array}$ & $\begin{array}{l}\text { Asset } \\
\text { struct. }\end{array}$ & $\begin{array}{l}\text { Invent. } \\
\text { turnov. }\end{array}$ & $\begin{array}{l}\text { Depr. } \\
\text { charg }\end{array}$ & ROI & $\begin{array}{l}R^{2} \\
\text { (adj.) }\end{array}$ \\
\hline Short term debt & $\begin{array}{c}0.122^{*} \\
(0.098)\end{array}$ & $\begin{array}{c}-0.410 \\
(0.054)\end{array}$ & $\begin{array}{c}0.005 \\
(0.002)\end{array}$ & $\begin{array}{c}0.542^{*} \\
(0.276)\end{array}$ & $\begin{array}{c}-0.016 \\
(0.004)\end{array}$ & 0.959 \\
\hline Long term debt & $\begin{array}{c}0.032^{*} \\
(0.076)\end{array}$ & $\begin{array}{c}0.394 \\
(0.041)\end{array}$ & $\begin{array}{c}-0.004 \\
(0.001)\end{array}$ & $\begin{array}{r}-0.174^{*} \\
(0.199)\end{array}$ & $\begin{array}{c}-0.008 \\
(0.003)\end{array}$ & 0.953 \\
\hline
\end{tabular}

Note: * means not significantly different from zero at a $5 \%$ level of significance.

As regards the effects of bankruptcy and agency costs, Table I shows that a high fixed asset component is associated with more long term debt and less short term debt, while the reverse is true for a high inventory turnover. Hence, debt categories apparently are related to the collateral value of the asset categories corresponding to turnover rate, i.e. the maturity structure of debt strongly relates to the "maturity structure" of assets. These results could indicate that rules of thumb, proclaiming that the time span of investments and their financing should be matched (the "golden balance sheet rule" as it is called in The Netherlands), have played an important role in the financial behavior of small firms over the period. ${ }^{19}$ The effect of profitability, based on Myers' pecking order argument, is supported for both short and long term debt: the coefficients for ROI are negative and significantly so in both cases.

Taken as a whole, the determinants considered here (except the tax effect) seem indeed to be relevant for the shoptypes involved, although they appear to influence the maturity structure of debt rather than its overall level. Finally, it is noted that the results obtained here are largely equivalent to those of earlier analyses of the same data set in which less elaborate estimation techniques are used (Van der Wijst, 1989, Van der Wijst and Thurik, 1990).

The second way in which the results are reported on is presented in Table II, in which a "decomposition analyses" is provided. This decomposition analysis involves the estimation of an OLS regression using the same transformed variables that were used in the LSDV analysis (except, of course, the dummies). The differences between the OLS and LSDV estimates spring from the dummy variables. These differences can be split up (decomposed) into a time specific and an industry specific component by regressing the time and industry dummies (separately) on the same set of explanatory variables that was used in the OLS and LSDV analyses. ${ }^{20}$ The results of these exercises are included in Table II, which also contains a set of estimation results regarding total debt. Since the corrections for autocorrelation and heteroskedasticity are done separately for long, short and total debt, the results do not add up vertically, only horizontally. In Table II, the OLS results are labelled 'total effect' because they represent the joint effects of the variables and the time and industry specific effects. The latter two are removed from the LSDV results which are, hence, labelled "pure variable effect".

The first column of Table II confirms, that a large part of the influences pertain to the maturity structure rather than the overall level of debt: the effects on the short and long term debt ratio are partly of opposite signs. The on balance results of the total debt ratio reflect the large proportion of short term debt in total debt. The decomposition of these results in the second, third and fourth column shows, that in the relations for long and short term debt the pure variable effects are dominant for most variables, except the insignificant size variable (total assets) and depreciation charges in the case of long term debt. The industry specific effects are usually larger than the time specific effects. For total debt, however, the industry specific effects are dominant for almost all variables, while the pure variable effects are largely insignificant because the effects on long and short term debt tend to cancel out. The composition of the effects of depreciation charges 
TABLE II

Decomposition of regression analyses results

\begin{tabular}{|c|c|c|c|c|}
\hline & $\begin{array}{l}\text { Total } \\
\text { effect }\end{array}$ & $\begin{array}{l}\text { Pure } \\
\text { variable } \\
\text { effect }\end{array}$ & $\begin{array}{l}\text { Industry } \\
\text { specific } \\
\text { effect }\end{array}$ & $\begin{array}{l}\text { Time } \\
\text { specific } \\
\text { effect }\end{array}$ \\
\hline \multicolumn{5}{|l|}{ Short term debt } \\
\hline intercept & 0.405 & 0.000 & 0.430 & -0.026 \\
\hline total assets & 0.245 & $0.122^{*}$ & 0.200 & $-0.077^{*}$ \\
\hline asset struct & -0.590 & -0.410 & -0.100 & -0.081 \\
\hline invent. turnov. & 0.009 & 0.005 & 0.003 & 0.001 \\
\hline depr. charg. & 0.615 & $0.542^{*}$ & 0.333 & $-0.260^{*}$ \\
\hline ROI & -0.030 & -0.016 & -0.009 & -0.005 \\
\hline \multicolumn{5}{|l|}{ Long term debt } \\
\hline total assets & 0.198 & $0.032^{*}$ & -0.057 & 0.223 \\
\hline asset struct & 0.545 & 0.394 & 0.091 & 0.061 \\
\hline invent. turnov. & -0.003 & -0.004 & 0.001 & $0.000^{*}$ \\
\hline depr. charg. & -0.504 & $-0.174^{*}$ & $-0.119^{*}$ & -0.211 \\
\hline ROI & $-0.002^{*}$ & -0.008 & $0.001^{*}$ & 0.004 \\
\hline \multicolumn{5}{|l|}{ Total debt } \\
\hline intercept & 0.497 & 0.000 & 0.516 & $-0.019^{*}$ \\
\hline total assets & 0.502 & $0.203^{*}$ & 0.193 & $0.107^{*}$ \\
\hline asset struct & -0.132 & $-0.037^{*}$ & -0.072 & $-0.022^{*}$ \\
\hline invent. turnov. & 0.007 & $0.002^{*}$ & 0.004 & $0.001^{*}$ \\
\hline depr. charg. & $0.119^{*}$ & $0.172^{*}$ & 0.428 & -0.482 \\
\hline ROI & -0.034 & -0.025 & -0.009 & $0.000^{*}$ \\
\hline
\end{tabular}

Note: ${ }^{*}$ means not significantly different from zero at a $5 \%$ level of significance.

on short term and total debt is particularly complex, consisting of large, opposite time and industry specific effects. We have no ready explanation for this result. On the other hand, the influence of asset structure on long and short term debt is comparatively straightforward, consisting almost entirely of pure variable effects with minor industry and time specific components. Summarizing, it can be concluded that the two way decomposition of the effects on total debt shows the influences on leverage to be much more complex than the coefficients of the simple test in the lower left hand corner of Table II suggest.

The third way in which results of the LSDV regression are reported on is presented in Figure 2. In this Figure, the coefficients of the 19 time dummies, obtained in the analyses of long and short term and total debt, are plotted against the years to which they refer. Figure 2 shows, that there is a distinct pattern in the values of the time dummy coefficients for short term and total debt.

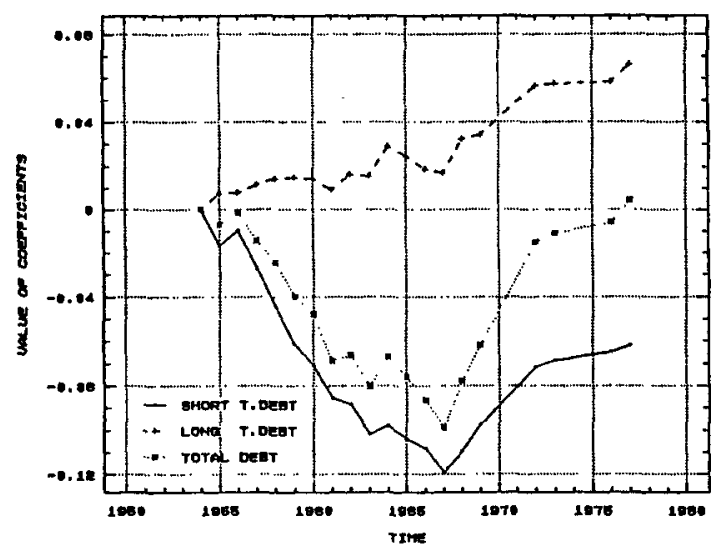

Fig. 2. Coefficients of time dummies

An almost monotonous decline of the values over the period 1955 through 1967 is followed by a similarly characteristic increase over the rest of the time span. The largely insignificant time dummy coefficients for long term debt show a much less clear development over time. A check on relevant macro economic variables (such as interest rates, inflation, economic growth, etc.) did not produce a variable with a corresponding pattern, so there is no ready explanation for the observed time structure in the values of the time dummies for short term and total debt. It should be noted however, that although the pattern in the time dummies is unmistakable, their contribution to the explanation of debt categories is limited. So the time structure in Figure 2 is a distinct but not a dominant factor in the analyses.

\section{Conclusions}

The present analyses of financial structure in a German panel of shoptype averages give rise to several conclusions. First of all, most of the determinants of financial structure presented by theory of finance appear indeed to be relevant for the small business sector investigated here. Nondebt tax shields, approximated by depreciation charges, of which no significant influences were found, are an exception. Secondly, however, the influences encountered in the analyses are far less straightforward than the hypothesized effects in the theory. Most variables influence the maturity structure of debt rather than leverage: the effects on long and short term debt tend to cancel out. 
This makes the influences on total debt not only smaller, but also more susceptible to industry and time specific effects. Thirdly, time and industry specific omitted variables, or commonalities in the variables used, also play an important role in the analyses of short and long term debt: the influence of a variable can consist for $50 \%$ or more of time and industry specific effects, but the pure variable effects are dominant in these analyses. Further, the time specific effects in the analyses of short term and total debt show a distinct pattern of steady decrease until 1967, followed by a steady increase over the rest of the period. We have no ready explanation for this phenomenon. As a concluding remark it can be noted that quantitative tests of the empirical implications of the theory of finance in small business are an extensive and promising area of research, although it is as yet largely neglected in the literature on both finance and small business.

\section{Acknowledgements}

An earlier version of this paper was presented at the 8th meeting of the EURO Working Group on Financial Modelling, November 1-3, 1990. We thank working-group members, Prof. Dr. J. Spronk and our colleagues at the Department of Fundamental Research for their helpful comments, and Erik M. Vermeulen and René G. J. den Hertog for computational assistance.

\section{Notes}

1 Some costs are reported to decrease with firm size, as is explained later on.

2 This division is adopted from Van der Wijst (1989), which contains a more comprehensive discussion of this subject; a short discussion of similar purport can be found in McConnell and Pettit (1984).

3 A discussion and empirical evidence regarding this clientele effect, as it is called, is provided by, among others, Copeland and Weston (1983).

4 Contract provisions may prohibit a borrower from incurring additional debt, from paying dividends, from removing assets from the business site, etc.

5 The data do not have a complete panel character: for some shoptypes information is available for less years than it is for others.

6 "Die Vermögens - und Kapitalsituation des Einzelhandels in dem Jahrzehnt 1954 bis 1963 " respectively "1964 bis 1973 " published in 1966 respectively 1975 in the series "Sonderhefte der Mitteilungen des Instituts für Handelsfor- schung an der Universität zu Köln" as Sonderheft 17 respectively 25 by Westdeutscher Verlag, Köln respectively Verlag Otto Schwartz, Göttingen and: "Die Vermögens - und Kapitalsituation des Einzelhandels in den Jahren 1976 und 1977" in: "Mitteilungen des Instituts für Handelsforschung an der Universität zu Köln", Jahrg. 31, no. 4, April 1979.

7 "Umsatz, Kostern, Spannen und Gewinn des Einzelhandeis in der Bundesrepublik Deutschland in dem Jahrzehnt 1949 bis 1958 " respectively " 1959 bis 1968 " respectively " 1969 bis 1978 " published in 1962 respectively 1970 respectively 1980 in the series "Schriften zur Handelsforschung" as Schrift no. 22 respectively 44 respectively 63 by the Westdeutscher Verlag, Köln, (n. 22 and 44) and Verlag Otto Schwartz, Göttingen (no. 63).

8 Bradley et al. include investment tax credits in their measure of non-debt tax shields and use $\mathrm{R} \& \mathrm{D}$ expenses as a separate indicator of non-debt tax shields; these variables are not available in the data at hand.

9 This variable is also used by, among others, Marsh (1982).

10 The inventories of shoptypes selling fast moving consumer goods (e.g. supermarkets) typically are accepted as collateral while the inventories of shoptypes selling goods subject to fashion, such as clothes shops, are not.

11 The share of retained earnings in equity, reflecting the possibility to retain earnings over an extended period of time, would be a better variable to capture the pecking order effect but unfortunately this variable is not available.

12 Information on prices is not available for all shoptypes; if information is missing, price indices of adjacent shoptypes or of total retailing are used.

13 See Hsiao (1986) p. 41-47, for a discussion of the pros and cons of fixed and random-effects models.

14 Including e.g. both the shoptype dummies and the averages across periods per shoptype would, of course, produce perfect multicollinearity.

${ }_{15}$ See e.g. Judge et al., 1982, chp. 14-15 for a description of this technique.

${ }_{16}$ The estimation procedure involves regressing the residuals on the residuals one period lagged.

17 For the first year of observation $u_{i t}^{*}=\left(\sqrt{1-\rho^{2}}\right) u_{i t}$ is used.

18 For the first year of observation $Z_{i 4}^{*}=\left(\left(\sqrt{1-\rho^{2}}\right) Z_{i t}\right) \div \sigma_{i}$ is used.

19 Recent research shows that this rule of thumb still influences financial policy in small business; see Van der Wijst $(1989$, p. 93) for a more detailed discussion and references.

20 For these analyses it must be assumed that the time dummies are the same for all shoptypes and that the shoptype dummies are the same for all periods. See Carree and Thurik (1990) where a comparable method is used to estimate the influence of entry barriers on retail profit margins.

\section{References}

Baxter, N. D., 1967, 'Leverage Risk of Ruin and the Cost of Capital', Journal of Finance 22 (4), 395-403.

Bradley, M., G. A. Jarell and E. H. Kim, 1984, 'On the Existence of an Optimal Capital Structure: Theory and Evidence', Journal of Finance 39 (3), 857-880.

Carree, M. and R. Thurik, 1990, Market Volatility, Entry 
Barriers and Retail Profit Margins, Research paper 9002, Research Institute for Small and Medium-Sized Business, Zoetermeer.

Castanias, R., 1983, 'Bankruptcy Risk and Optimal Capital Structure', Journal of Finance 38(5), 1617-1635.

Copeland, T. E. and J. F. Weston, 1983, Financial Theory and Corporate Policy, Reading (MA): Addison-Wesley.

Dielman, T. E., 1989, Pooled Cross-Sectional and Time Series Data Analysis, New York: Marcel Dekker.

Ferri, M. G. and W. H. Jones, 1979, 'Determinants of Financial Structure: A New Methodological Approach', Journal of Finance 34(3), 631-644.

Flath, D. and C. R. Knoeber, 1980, 'Taxes, Failure Costs, and Optimal Industry Capital Structure: An Empirical Test', Journal of Finance 35(1), 99-117.

Haley, C. and L. Schall, 1979, The Theory of Financial Decisions, New York: McGraw-Hill.

Hsiao, C., 1986, Analysis of Panel Data, Cambridge: Cambridge University Press.

Jensen, M. C. and W. H. Meckling, 1976, 'Theory of the Firm: Managerial Behaviour, Agency Costs and Ownership Structure', Journal of Financial Economics 3, 305-360.

Keasey, K. and P. McGuinness, 1990, 'Small New Firms and the Return to Alternative Sources of Finance', Small Business Economics 2(3), 213-222.

Kim, E. H., 1978, 'A Mean-Variance Theory of Optimal Capital Structure and Corporate Debt Capacity', Journal of Finance 33(1), 45-63.

Leland, H. E. and D. H. Pyle, 1977, 'Informational Asymmetries, Financial Structure, and Financial Intermediation', Journal of Finance 32(2), 371-387.

Marsh, P., 1982, 'The Choice Between Equity and Debt: An Empirical Study', Journal of Finance 37(1), 121-144.

McConnell, J. J. and R. R. Pettit, 1984, 'Application of the Modern Theory of Finance to Small Business Firms', in P. M. Horvitz and R. R. Pettit (eds.), Small Business Finance 1, Greenwich, Connecticut: JAI Press.

Miller, M., 1977, 'Debt and Taxes', Journal of Finance 32(2), $261-275$.

Modigliani, F. and M. Miller, 1958, 'The Cost of Capital' Corporation Finance and the Theory of Investment', American Economic Review 48(3), 261-297.
Modigliani, F. and M. Miller, 1963, 'Taxes and the Cost of Capital: A Correction', American Economic Review $53(3), 433-443$.

Myers, S. C., 1977, 'Determinants of Corporate Borrowing', Journal of Financial Economics 5, 147-175.

Myers, S. C., 1984, 'The Capital Structure Puzzle', Journal of Finance 34 (3), 575-592.

Myers, S. C. and N. Majluf, 1984, 'Corporate Financing and Investment Decisions When Firms Have Information Investors Do Not Have', Journal of Financial Economics $34(3), 17-34$.

Norton, E., 1990, 'Similarities and Differences in Small and Large Corporation Beliefs about Capital Structure Policy', Small Business Economics 2(3), 229-245.

Rapoport, J., 1990, 'Financing of Technological Innovation by Small Firms: Case Studies in the Medical Device Industry', Small Business Economics 2(1), 59-71.

Remmers, L., A. Stonehill, R. Wright and T. Beekhuisen, 1974, 'Industry and Size as Debt Ratio Determinants in Manufacturing Internationally', Financial Management (2), 24-32.

Robichek, A. A. and S. C. Myers, 1965, Optimal Financing Decisions, Englewood Cliffs: Prentice Hall.

Ross, S. A., 1977, 'The Determination of Financial Structure: The Incentive-Signalling Approach', Bell Joumal of Economics 8, 23-40.

Scott, D. F., 1972, 'Evidence on the Importance of Financial Structure', Financial Management 2(2), 45-50.

Scott, D. F. and J. D. Martin, 1975, 'Industry Influence on Financial Structure', Financial Management 4(1), 67-73.

Walker, D., 1989, 'Financing the Small Firm', Small Business Economics 1(4), 285-296.

Warner, J., 1977, 'Bankruptcy Costs: Some Evidence', Journal of Finance 17(2), 337-347.

Wijst, D. van der, 1988, Determinants of Financial Structure in Retailing, Research Paper 8801, Research Institute for Small and Medium-Sized Business, Zoetermeer.

Wijst, D. van der, 1989, Financial Structure in Small Business, Theory, Tests and Applications, Berlin: Springer-Verlag.

Wijst, D. van der and A. R. Thurik, 1990, Determinants of Small Firm Debt Ratios, Research Paper 9005, Research Institute for Small and Medium-Sized Business, Zoetermeer. 
Appendix. Shoptypes and key financial data per shoptype.

\begin{tabular}{|c|c|c|c|c|}
\hline Shoptype & $\begin{array}{l}\text { CURR } \\
\text { TAA }\end{array}$ & $\begin{array}{l}\mathrm{EQ} \\
/ \mathrm{TA}\end{array}$ & $\begin{array}{l}\text { TOTAL } \\
\text { ASSETS }\end{array}$ & SALES \\
\hline 1 LEBENSMITTELEINZELHND & 0.625 & 0.202 & 120.57 & 816.73 \\
\hline 2 TABAKWARENEINZELHND & 0.851 & 0.098 & 70.30 & 512.22 \\
\hline 3 TEXTILEINZELHND HERRENOBERBEKLEIDUNG & 0.741 & 0.089 & 522.39 & 1594.60 \\
\hline 4 TEXTILEINZELHND DAMENOBERBEKLEIDUNG & 0.719 & 0.110 & 427.37 & 1553.76 \\
\hline 5. TEXTILEINZELHND HERREN-, DAMEN-BEKL. & 0.704 & 0.082 & 928.31 & 2656.20 \\
\hline 6 TEXTILEINZELHND HERRENAUSSTATTUNG & 0.758 & 0.115 & 223.63 & 674.88 \\
\hline 7 TEXTILEINZELHND WAESCHE, WIRK-STRICKWAREN & 0.779 & 0.088 & 234.59 & 716.34 \\
\hline 8 TEXTILEINZELHND HAUS-UND BETTWAESCHE usW. & 0.624 & 0.106 & 321.07 & 938.09 \\
\hline 9 TEXTILEINZELHND MIT GEMISCHTEM SORTIMENT & 0.700 & 0.081 & 687.61 & 1762.12 \\
\hline 10 SHUHEINZELHND & 0.749 & 0.092 & 303.66 & 770.54 \\
\hline 11 MOEBELEINZELHND & 0.675 & 0.055 & 1056.10 & 2610.20 \\
\hline 12 GLAS-, PORZELLAN-UNK KERAMIKEINZELHND & 0.728 & 0.100 & 337.13 & 855.03 \\
\hline 13 ELSENWAREN-UND HAUSRAT VORW KUECHENGER. & 0.726 & 0.073 & 294.14 & 764.67 \\
\hline 14 ELSENW.-UND HAUSR. VORW BAUBESCHLAEGEN & 0.785 & 0.053 & 778.05 & 1953.31 \\
\hline 15 ELSENWAREN-UND HAUSRATHND GEMISCHT SORT. & 0.736 & 0.060 & 671.63 & 1619.46 \\
\hline 16 BELEUCHTUNGS-UND ELEKTROEINZELHND & 0.711 & 0.076 & 471.65 & 1233.41 \\
\hline 17 RADIO-UND FERNSEHEINZELHND & 0.778 & 0.092 & 414.92 & 1171.57 \\
\hline 18 TAPETEN-UND BODENBELAGHND & 0.756 & 0.082 & 555.28 & 1708.31 \\
\hline 19 DROGERIEN & 0.703 & 0.142 & 130.64 & 426.45 \\
\hline 20 LEDERWAREN-UND GALANTERIEWARENHND & 0.740 & 0.108 & 231.63 & 708.46 \\
\hline 21 PHOTOEINZELHND & 0.766 & 0.147 & 331.65 & 1143.48 \\
\hline 22 UHREN-, JUWELEN-, GOLD-, UND SILBERWARENHND & 0.821 & 0.083 & 389.56 & 689.57 \\
\hline 23 SPORTARTIKELEINZELHND & 0.778 & 0.095 & 369.24 & 1122.13 \\
\hline 24 SORTIMENTSBUCHHND & 0.830 & 0.103 & 231.28 & 1034.73 \\
\hline 25 PAPIER-, BUEROBEDARF-UND SCHREIBWARENHND & 0.762 & 0.106 & 250.87 & 936.06 \\
\hline 26 BUEROMACHINEN-, BUEROMOEBELHND & 0.805 & 0.079 & 1066.14 & 3897.77 \\
\hline 27 BLUMENBINDEREIEN & 0.592 & 0.262 & 62.20 & 425.82 \\
\hline
\end{tabular}

Note: The first column (CURR/TA) contains current assets divided by total assets and the second column (EQ/TA) contains the ratio of equity to total assets. The third and fourth column show total assets and sales respectively in $10^{3} \mathrm{DM}$, current prices. All figures refer to data averaged over 20 years of observation. 